\title{
Covid Handling in Aceh; Cultural Communication Perspective
}

\author{
Rahmadianawati ${ }^{1}$, Zulfikar A. Makam ${ }^{2}$, Zulfikar AR ${ }^{3}$, Oknita $^{4}$, Said Mahdi
}

1,2,3,4,5 Universitas Islam Negeri Sumatera Utara Medan, Indonesia

\begin{tabular}{|c|c|}
\hline ARTICLE INFO & ABSTRACT \\
\hline Article history: & \multirow{13}{*}{$\begin{array}{l}\text { The Covid-19 pandemic phenomenon has caused global panic to all } \\
\text { aspects of people's lives. The Government of Aceh implements } \\
\text { various policies, including social distancing, quarantine, and holding } \\
\text { cells to break the chain of virus spreading. An interesting thing to } \\
\text { study from the perspective of cultural communication is the } \\
\text { traditional, cultural, and religious traditions in Aceh so that Aceh has } \\
\text { its uniqueness in facing the threat of Covid -19. Acehnese people } \\
\text { have unique rituals from generation to generation to fight the plague } \\
\text { that is happening. After a patient died of Covid-19 on } 23 \text { March } \\
2020 \text {, the Acehnese held a remembrance and prayer rejecting the } \\
\text { plague by gathering in places of worship or open fields until a torch } \\
\text { parade surrounded the boundaries of each village guided by leaders } \\
\text { and leaders religion, by applying the protocol established by the } \\
\text { government. This case shows a balance between effort and prayer. At } \\
\text { first glance, there is a contradiction between the social distancing } \\
\text { recommendations and the ritual of rejecting the plague. It also has the } \\
\text { support of various parties from several local authority holders. } \\
\text { According to the report of the Aceh Covid Cluster and Covid } \\
\text { Indonesia Task Force, } 2 \text { June } 2020,14 \text { city districts in Aceh entered } \\
\text { the green zone. Just a small proportion comes into the red zone with a } \\
\text { small number of PDPs, namely } 20 \text { PDPs, } 17 \text { recovered, and one } \\
\text { person died, so Aceh should be a pilot area in handling Covid-19. }\end{array}$} \\
\hline Received Aug 7, 2020 & \\
\hline Revised Aug 20, 2020 & \\
\hline Accepted Sept 18, 2020 & \\
\hline Keywords: & \\
\hline Covid, & \\
\hline Cultural Communication, & \\
\hline Prayer Rejecting The Plague, & \\
\hline & \\
\hline Clonflict of Interest: & \\
\hline None & \\
\hline Funding: & \\
\hline None & \\
\hline
\end{tabular}

Corresponding Author: Rahmadianawati. Universitas Islam Negeri Sumatera Utara Medan. Email: rahmadianawati72@gmail.com

\begin{tabular}{l} 
(C) $\left(\begin{array}{l}\text { C Rahmadianawati, Zulfikar A. Makam, Zulfikar AR, Oknita, Said Mahdi } \\
\text { This is an open access article under the CC BY-SA 4.0 international license. }\end{array}\right.$ \\
\hline
\end{tabular}

1. Introduction

\subsection{Introduce the Problem}

In the Republic of Indonesia Law Number 11 of 2006 concerning Aceh Governance, it is stated that Aceh is a province that is a special legal community unit. Aceh is given special authority to regulate and manage government affairs and the interests of the local community by itself in accordance with the 1945 Constitution, which is led by a Governor. Wali Nanggroe and Tuha Nanggroe are institutions that are symbols for the preservation of the implementation of customary life, culture, and that unites the community in Aceh Province. Based on BPS Aceh data dated February 24, 2020, it was noted that the population of Aceh in 2019 was in the range of 5,371,532 people with the majority of the population being Muslim. Aceh has special rights in the fields of religion, customs, and education. This special right has been granted to Aceh since 1965, as stated in Law of the Republic of Indonesia Number 18 of 1965 concerning the Principles of Regional Government.

In 2020, Covid-19 became a world problem, so the World Health Organization (WHO) on December 31, 2019, announced a collection of pneumonia cases with unclear etiology in Wuhan City, Hubei Province, China. This case continued to get worse until it was finally discovered that the cause of this pneumonia cluster was the new coronavirus (Safrizal ZA et al, 2020: 2). On February 12, 2020, WHO officially designated the novel coronavirus disease in humans as Coronavirus Disease (Covid-19). Coronavirus (Covid- 
19) has spread throughout the world to Indonesia, initially this occurred due to direct contact with foreign nationals visiting Indonesia, through trade and tourist routes. Previously, the spread of the Covid-19 virus only took place outside of Aceh Province, due to official travel of Aceh officials outside the region, causing the transmission to have an impact on the family and surrounding communities and their homes in Aceh. The SARS-CoV-2 virus is thought to spread between people mainly through droplet droplets produced during coughing or sneezing. In addition, the virus can spread by touching contaminated surfaces and then touching someone's face. Covid-19 is most contagious when people who have it have symptoms, although it may spread before symptoms appear. The time period between exposure to the virus and the appearance of symptoms is usually around five days but can range from two to fourteen days. Common symptoms include fever, cough, and shortness of breath. Complications can include pneumonia and severe acute respiratory disease. The primary treatment given is symptomatic and supportive therapy. Recommended preventive measures include washing hands, covering your mouth when coughing, keeping your distance from other people, and monitoring and self-isolation for people who suspect they areinfected.

To prevent its spread, the government restricted travel, closed airports, train stations, and border checks of entry areas and restricted the movement of local transmissions. In addition, it also implements quarantine for Corona Positive Patients, enforces curfews, postponements, and cancellations of events, and closes educational facilities and tourist attractions. Likewise, the implementation of worship activities is also limited, recitation at the Recitation Center, Dayah, Al-Qur'an Education Park, and Majlis Taklim, many recitations must be closed as an effort to break the chain of spreading the virus. Teachers and all ASN are required to temporarily work from home (Work From Home). In addition, this pandemic has caused global socio-economic disruption and public concern about the scarcity of food and clothing. The information gap regarding this virus has caused deep fear and concern among the people of Aceh, especially the middle and upper economic community. Unlike the case with low-income people, they are not affected by this pandemic. For them, the most important thing is that the family's clothing and food needs must be met so that they do their activities as usual. In reality in the field, even though the government has issued a regulation related to this pandemic, in the implementation of worship, both Friday prayers, Tarawih, Witir, and Eid prayers, everything is running as usual. As of June 2020, Aceh is still categorized as a Green Zone. This is what motivates the author to research "Handling Covid in Aceh (Cultural Communication Perspective)".

\section{Literature Review}

\subsection{Cultural Communication}

Cultural communication is communication that occurs between people who have different cultures (can be different races, ethnicities, or socioeconomics, or a combination of all these differences. Culture is a way of life that develops and is adopted by a group of people and lasts from generation to generation) (Stewart L. Tubbs \& Sylvia Moss, 2005: 68) According to Stewart, socio-cultural communication is communication that occurs in a condition that shows differences in socio-cultural backgrounds such as social strata, language, values, customs, and habits. Thus, cultural communication is a communication process that involves people from different socio-cultural environments. This communication occurs when two or more people with different socio-cultural backgrounds interact (Suranto Aw, 2015: 68).

\subsection{Health Communication}

Cultural and religious factors have a relationship with medicine, on the one hand, these two factors are relevant in medicine because they influence beliefs about the nature of the disease and their ability to cope with disease or adhere to recommended treatment (Schiavo, 2007: 76). Tradition, habit, ethnicity, culture, religion, and beliefs also influence ideas of health and disease among various groups. In health communication, these values and beliefs are very important in designing and implementing programs that can reach across cultural boundaries and produce behaviors and societies (Schiavo, 2007: 71).

\subsection{Symbolic interactionism}

Symbolic interactionism is the name given to the theoretical perspective of the writings of George Herbert Mead. This theory argues that humans are social creatures; individual identities are not only created but also symbolic or social products. Humans are conceptualized as actors who are always seen with other people in a communal symbolic world, which always contains meaning. To understand the meaning of something, one must understand how to act on something, how to attract objects to future actions. Understanding of meaning is as behavior and directed at questions about the place of future meaning into the world of social interaction (Stephen W. Littlejohn \& Karen A. Foss, 2016: 747-748). Based on the interactional perspective, symbolic interaction assumes that each individual has a cultural essence, interacts in social society, and produces 
mutually agreed-upon meanings of "thought" (Ardianto, 2007: 40).

\section{Research Methods}

This study uses a qualitative research method because the data holistically describe social reality, used to examine the condition of natural objects (Sugiyono, 2017: 9). Qualitative research aims to understand social phenomena that arise in society by describing them in the form of words and language (Lexy J. Moleong, 2005: 6). Bogdan and Biklen define qualitative methodology as a research procedure that produces descriptive data in the form of written or spoken words from people and observable behavior (Syukur Kholil, 2006: 121). This research uses a case study approach, namely: an investigative strategy in which the researcher explores in depth some or all of the activities and processes of the phenomenon being studied. Researchers collect detailed information by using various data collection processes over a continuous period (John W. Creswell, 2009: 13). The data collection technique is done by triangulation, data analysis is inductive, and the results of the research are more emphasized on meaning rather than generalization.

\section{Results and Discussion}

\subsection{Development of the Covid-19 Pandemic in Aceh}

As reported by Antara, the first Covid-19 case in Aceh first appeared on March 23, 2020. A patient under surveillance (PDP) who died at the Zainoel Abidin Regional General Hospital (RSUD) Banda Aceh on Monday, March 23, 2020, one of the managers of Perta Arun Gas (PT. PAG), with the initials AA, was confirmed positive for Covid-19. This patient is the first case report in Aceh Province. The male patient who tested positive had a history of travel to Surabaya and Bogor, the areas that first reported exposure to Covid. According to the latest diagnosis, the 56-year-old patient has a lung infection. In the next case, on Friday 24 April 2020, two Acehnese citizens tested positive for Coronavirus. The two patients are MS, male, 47 years old, by profession as a security officer from Aceh Besar, and the US, a woman, 42 years old, from Aceh Barat Daya. The two patients tested positive based on the results of their swab examinations at the Real-Time Polymerase Chain Reaction (RT-PCR) Laboratory owned by Balitbangkes Aceh, Siron area, Kecamatan Ingin Jaya, Aceh Besar. Director of the General Hospital Dr. Zainoel Abidin (RSUZA) Banda Aceh, Dr. Azharuddin, said MS tested positive for Corona after the results of his swab came out on Thursday, April 23, 2020 , in the afternoon and was received by RSUZA, Friday, 24/4/2020 morning.The specimen was taken from his throat on April 17, 2020. The patient under surveillance (PDP) was isolated and treated in the Respiratory Intensive Curative Unit (RICU) RSUZA. It was also reported that he had just returned from Jakarta. Because there was a complaint of a sore throat and his body temperature increased above normal, so that a nasopharyngeal and oropharyngeal swab was carried out, the result was positive for Covid-19.About AS, specimen collection from his throat was also carried out on the same day, April 17, 2020, at RSUZA. Then, the AS swab specimens were examined at the RT-PCR Laboratory belonging to the Aceh Balitbangkes. The results of the swab examination came out on Friday (4/24/2020) afternoon. In the cover letter for the results of the swab signed by examiner, Miss Rahmaida Puetri, it was stated that As was also positively infected by Corona. Azharuddin revealed that the results of As patient's swab were unique. Formerly AS was tested positive for Corona based on the results of the rapid test at the Teungku Peukan General Hospital (RSUTP) Blangpidie, Abdya. Then, he was referred to RSUZA and his throat mucus samples were taken to be sent to the Jakarta Health Laboratory Center. A week later, Saturday (18/4/2020) afternoon, the results of the As swab examination were issued by the Jakarta Health Laboratory Center.The results of this swab were only received by RSUZA on Sunday (19/4/2020) afternoon, and AS was tested negative for Corona. "Initially he was treated at RICU RSUZA. Because his clinical condition had improved, he was subsequently treated in the Covid-19 Pinere RSUZA Room. After the results of the smears were negative, AS was allowed to return to Abdya. Moreover, while being treated at RSUZA, his clinical condition improved. Before returning home, AS was checked again at the RT-PCR Laboratory of Aceh Balitbangkes. The results of the swab came out on Friday, 24 April 2020 afternoon, and were tested. Then, the data released by the Covid-19 Posko Health Service on Thursday, 30 April 2020 at 3:00 p.m. WIB, there was another positive corona sufferer in Aceh, namely AJ (20), from Aceh Tamiang. AJ was a group of students from Magetan, East Java who returned to Aceh. Furthermore, positive patients continued to increase, but almost all of them recovered. According to reports from the Aceh Covid Group and the Indonesian Covid Task Force, 2 June 2020, 14 districts/cities in Aceh are in the green zone and only a small portion is in the red zone with a small number of PDP, namely 20 PDP, 17 recovered, 2 in treatment and one person died, so Aceh must become a pilot area for handling Covid-19. 


\subsection{The Role of the Government, Ulama, and Community Leaders in Handling Covid-19 in Aceh}

Aceh has special features in the field of religion, apart from being the first area for the entry of Islam in Indonesia, as well as a center for the development of Islamic civilization in Southeast Asia. 98,89\% of the population is Muslim (Marzuki Abubakar, 2017: 29). The administration of Indonesia places Aceh as a special regional government unit and has special authority, related to the historical characteristics of the struggle of the Acehnese people who have high resilience and fighting power, originated from a view of lifebased on Islamic law that makes a strong Islamic culture. The people of Aceh implement the principles of Islamic personality regardless of nationality, position and status in their area according to the boundaries of the Aceh Province. The Aceh Governance Law is inseparable from the Memorandum of Understanding between the Government and the Free Aceh Movement, which signed on 15 August 2005, and is a form of dignified reconciliation towards sustainable social, economic, and political development in Aceh. Law Number 11 of 2006, which contains 273 articles, constitutes the Regional Government Law for Aceh in particular. The material of the law, the specificity, and distinctiveness of Aceh constitute the main framework of Law Number 11 of 2006, mostly similar to Law Number 32 of 2004 concerning the Regional Government. Therefore Aceh is no longer dependent on the Regional Government Law (as long as matters have been regulated according to the Aceh Government Law). In efforts to overcome the spread of the coronavirus in Aceh, the Government of Indonesia established a referral hospital to accommodate Covid-19 patients, namely: RSUD Dr. Zainal Abidin Banda Aceh, RS. Cut Mutia Lhokseumawe, Meuraxa Hospital Banda Aceh, RSUD Tgk. Chik Di Tiro, Pidie Regency, Dr. Fauziah, Bireuen Regency, Dr. H. Yuliddin Away Tapaktuan, Langsa Hospital, Datu Beru Central Aceh Hospital, Nagan Raya Regional Hospital, Tgk. Pekan Aceh Barat Daya, RSUD dr. Zubir Mahmud IDI East Aceh, Gayo Luwes Regional Hospital, and H. Sahudin Kutacane Regional Hospital. In line with the central government's policy, the Aceh and district/city governments began to follow suit by issuing a policy of two weeks of school holidays. The regional head must issue instructions to his staff to temporarily stop traveling abroad, outside the region and within the region, except for urgent matters, either using a personal budget, let alone the state budget.

On April 3, 2020, the Aceh Government conducted a comprehensive evaluation of policies related to the prevention of Covid-19 that had been carried out during the last three months (January-March) in a joint meeting held in the Aceh Regional Secretary room. During the meeting, Aceh Covid-19 Spokesperson, Saifullah Abdulgani, said that the evaluation concerns efforts to improve the orderliness of people's lives by considering social restrictions as an emergency response, one of which is the Joint Declaration of Forkopimda Aceh dated March 29, 2020, concerning the Implementation of Curfews. This decree is following Presidential Decree Number 7 of 2020 concerning the Task Force for the Acceleration of Handling Corona Virus Disease 2019 (Covid-19), Presidential Decree Number 9 of 2020 concerning Amendments to Presidential Decree Number 7 of 2020 concerning the Task Force for the Acceleration of Handling of Covid19, and Aceh Qanun Number 4 of 2010 concerning Health. The curfew policy has been the pros and cons of society, some people think that this is very useful in an effort to break the chain of Covid-19 transmission, but some other people complain that the Declaration on the Application of Curfew has a negative to social and economic conditions of the community. On March 31, 2020, the Central Government issued Government Regulation Number 21 of 2020 concerning Large-Scale Social Restrictions in the context of the Acceleration of Handling Covid-19. In connection with this, the Aceh Government evaluates the Declaration on the Application of the Nighttime to take further steps. The next policy is guided by Government Regulation Number 21 of 2020, and the results of the Forkopimda agreement. At the same time, the Aceh Government urges people to stay at home, worship at home, study at home, work at home, apply the principles of maintaining the distance between people (physical distancing), maintaining unity, oneness, and cohesiveness, and cooperation to fight Covid-19. The Aceh government also urges to be careful and wise in consuming news from social media that is not necessarily true (hoax).

On April 6, 2020, the Minister of Religion issued Circular Number 6 of 2020 concerning the Implementation of Ramadan and Eid Prayer 1 Syawal 1441 H. in the midst of the Covid-19 pandemic. In this case, the Aceh Government follows up on the Circular of the Minister of Religion, namely: "Muslims are required to fast properly in the month of Ramadan based on the provisions of fiqh worship; Suhoor and breaking the fast are carried out by individuals or nuclear families, Tarawih prayers are performed individually or in the congregation with the nuclear family at home; the implementation of the Eid al-Fitr prayer in congregation in mosques and in the field is eliminated; halal bi halal during Eid al-Fitr through social media and video call conferences. On March 31, 2020, MPU Aceh assembly issued Decree Number 4 of 2020 regarding the implementation of Worship and other socio-religious activities in an emergency. The essence of the decree is: every Muslim is obliged to make every effort to protect and keep himself away from the epidemic of 
infectious diseases by always praying, doing dhikr and praying and paying attention to medical instructions; It is permissible for a Muslim not to pray in congregation in mosques, meunasah or mushalla and not to pray on Friday, but is obliged to replace it with Zuhr prayer at his respective residence; obliged to pay attention to medical procedures and health protocols such as distance between congregations (physical distancing); The public is asked not to hold crowd events in the form of tasyakkuran, feast, tahlil, samadiah, and dhikr together etc. until the condition of the dharurat is lifted; people are advised not to travel outside the region, and those who are overseas do not return to Aceh, except because it is very urgent and willing to be quarantined by the government; The public is asked to comply with the instructions and protocols established by the government in dealing with the Covid 19 epidemic, including not leaving the house during curfews and maintaining a safe distance in crowded places (social distancing).

If we look closely, the policies taken by the Aceh Government and the MPU are in line with the Indonesian Government's policies in an effort to overcome the Covid-19 Pandemic. Unlike the Acehnese ulama, especially those from the Dayah community, they have different views in dealing with the Covid-19 outbreak in Aceh. Ulama have a very important role in the life of the Acehnese people, they are responsible for issuing fatwas on religious matters and advising and improving the basic governance of the Islamic State, following the understanding of teachings sourced from the Qur'an and al-hadith. Since Islam entered Aceh (800 AD) until 1903, no other educational institutions in Aceh except Dayah. The role of scholars in the past, both teaching and writing a number of books have been able to influence the thinking of Muslims in Southeast Asia and bring the fragrant name of Aceh so that it is nicknamed the Serambi Makkah (Abuya H. Muhibuddin Waly Al-Khalidy et al, 2008: 171). Alim ulama in Aceh called on all Muslims in Indonesia to hold dhikr together and increase prayers in mosques and prayer rooms. Besides, the village Imam invited the congregation to carry out a ritual of expelling disease by saying the call to prayer and reciting verses from the Al-Qur'an. Responding to the Coronavirus in Aceh, Aceh's Charismatic Ulama, Tgk H Muhammad Ali or Abu Paya Pasi directed the Acehnese to surround the village while making the call to prayer and reading verses from the Qur'an such as "Waqul Jaa Al Haqqu Wazahaqal Baathil, Innal Baathila Kaana Zahuuqa." Leader of Dayah Bustanul Huda Julok also advised all recitation congregations and Muslims, especially in Aceh, not to shut themselves up at home, let alone vacate the mosque. In addition, Muslims must prosper the mosques and make it an opportunity to get closer to Khaliq (Allah SWT). Abu Paya Pasi said that the virus of COVID-19 can be overcome by wudhu' and prosper the mosques. Every fardhu prayer, the Imam should reads the qunut nazilah on the last rak'ah. At first glance, Abu Paya Pasi's message contradicts policies set by the government so that people to stay at home, social distancing, and lockdown during the Covid-19 pandemic.

The obedience of the Acehnese people to the ulama was visible in everyday life. In general, they continue to carry out their daily activities as usual, especially who work as farmers, laborers, and traders. In their mind is to make a living to meet the needs of their family. Only a handful of Acehnese people, especially those who work in Government Agencies and urban areas, remain obedient to Government instructions by implementing Work From Home and implementing health protocols. Likewise in the implementation of worship at the Mosque and Meunasah, especially during Friday Prayers, Tarawih prayers, as well as Eid alFitr prayers, the implementation of worship goes on as usual. The issues about the dangers of Covid-19 have not any impact to the Acehnese rural people, the belief in the hearts of the Acehnese people that wudhu' 'can prevent them from the danger of the Covid-19 pandemic. The limbs that are cleaned during wudhu' where the frequency of activity is more dominant have the potential to come into contact with the virus, such as hands, face including mouth and nose, head including ears, and feet. Clothing and the place used must also be free from unclean. Even our scholars recommend that we often do wudhu ', even if just want to do daily activities. Wudhu' is one of the rituals and preventive habits against disease transmission (Faried F. Saenong et al, 2020: 9-10). The appeal of health experts to wash hands frequently is an affirmation of the tradition of taharah in Islam. It needs to be underlined that all positive cases of corona in Aceh originate from residents who had history of return from the red zone and were positively contaminated upon arrival in Aceh. Aceh is considered successful in suppressing the spread of the Coronavirus because of the public's obedience to leaders and scholars, as well as obedience in maintaining religious obligations.

\subsection{Attitudes and Traditions of the Acehnese People in Facing the Plague and Tha'un (Covid-19)}

According to the view of the people of Aceh, Islam is a religion that is rahmatan lil 'alamin. When Covid-19 hit the whole world, Muslims sought lessons from the historical record of Islam. Hadith and history books provide various answers about tha'un, judzam, barash, and others. Some Acehnese people believe in solutions from the medical world such as isolating themselves from society, avoiding physical contact with sufferers, and the importance of fighting for treatment. Some people who are passive and don't care about government 
regulation, they believe that it is the creator's provision. Meanwhile, some of them follow the procedure, which is also accompanied by prayer. The conclusions of the decisions and attitudes taken are explored with a takwil approach to the text in the hadith book. For example in the hadith narrated by Aisyah ra. when many of the Prophet's companions were stricken with the plague of barash, the Prophet temporarily forbade Aisha and her other friends to visit those affected by the plague. The conclusion from this hadith is the importance of the concept of self-isolation. The concept of isolation is strengthened by interpreters of classical texts with another hadith which reads: "Do not keep looking for (approaching) people suffering from judzam disease," (Narrated by Ibn Majah). This hadith is considered authentic and according to medical theory, the virus that causes leprosy is easily transmitted between humans so that the Prophet Muhammad forbade his followers to approach people affected by the plague. The concept of this hadith also leads to the quarantine method implemented by the government to prevent the spread of the corona virus. In responding to Covid-19, countries in the world apply the principle of isolation, such as the cancellation of all types of flights between countries, advice not to have physical contact with just anyone, and the struggle of scientists to find the anticorona virus. As a country with the largest Muslim population in the world, at least this provides moral legitimacy for Indonesia's current state policy. Islam as a religion of rahmatan lil 'alamin must be interpreted by Indonesia as a social, political, economic and religious attitude that is based on science. Not only carrying out health protocols that have been established by the government, the city nicknamed Bumi Serambi Makkah is very thick with religious values in warding off plague or disaster. Other regions in Indonesia were also asked to imitate the Aceh region in terms of handling Corona.

The provisions for implementing Islamic shari'ah in Aceh are regulated by the Qanun, namely: every Muslim in Aceh is obliged to obey the practice Islamic, and, every person in Aceh is obliged to respect the implementation of Islamic law. The Aceh Government and District/City Governments guarantee freedom, foster harmony, respect religious values adhered to by religious communities and protect fellow religious communities to carry out worship under their religion. The establishment of places of worship in Aceh must obtain permission from the Aceh Government or District/City Governments. As a religious community, the implementation of religious life in Aceh is also filled with communication activities, especially to the creature's relationship with the Khaliq, which is known as prayer. Prayer is the delivery of a man's message to God. Through prayer, humans communicate their desire to God. When facing difficulties and inconveniences, humans increasingly communicate (pray) to Allah, so that Allah will immediately eliminate all these difficulties. Communication in a ritual perspective is carried out to maintain togetherness and community solidarity. Communication activities (use of messages) are for sharing, participation, association, fellowship, maintaining the same belief (the possession of common faith). The communication process in this view is like to a sacred ceremony where everyone is in an atmosphere of friendship and togetherness. The message conveyed in ritual communication is usually hidden (latent) and has a double meaning (ambiguity), depending on the relationships and symbols available in a culture, not symbols made by communication participants.

From a communication point of view, culture can be defined as a complex combination of common symbols, knowledge, folklore, customs, language, information processing patterns, rituals, habits and other patterns of behavior that are related and give a common identity to a group. In society, communication is how individuals create, share and perpetuate culture. (Brent D. Ruben and Lea P. Stewart, 2014: 359-361). Without the capacity of symbolic language, we would not be able to develop a shared culture, and impossible to convey cultural elements from one place to another, or from one generation to the next. Thus, culture and communication influence each other reciprocally, through communication we shape the culture that ultimately the culture shapes communication patterns. One of the traditions of the Acehnese people that has been carried out from generation to generation in the face of outbreaks such as the Corona virus is to do prayer and dhikr together. This tradition is carried out by gathering in the open field after Isha prayer while still performing ablution 'and doing dhikr together in a sitting position guided by murshid and religious leaders. Another way is to walk in groups, around the city borders and the local village by carrying a torch. Reading prayers and dhikr simultaneously, as was done by residents of the Meunasah Alue village in Cunda District, Muara Dua District, Lhokseumawe City on Thursday, March 19, 2020. Likewise the residents of Gampong Uteun Bayi, Banda Sakti District, Lhokseumawe City and Santri Babur Ridhah Al-Alziziyah, they held dhikr torch to reject the plague Coronavirus which is currently hitting the Acehnese people in particular and the world community in general. The dhikr of the torch is carried out after the Isya prayer, while still performing ablution 'for three consecutive days (22-24 March 2020), while doing dzikir students and residents surround the remote areas of the village. The activity was attended by hundreds of enthusiastic santri and residents from various ages of men and women. Zikir, Shalawat and Asmaul Husna's words while 
carrying the torch are a tradition of the people in Aceh to expel and clean Gampong from disease outbreaks (Corona Virus). Several other places in Aceh, such as Takengon, Banda Aceh, and Bireuen do the same thing, of course without ignoring the efforts and protocols set by the government, meaning a balance between effort and prayer. In addition, the Acehnese people continue to pray in congregation at the mosque. If congregational prayers at the mosque can cause many positive victims of Covid-19, it is certain that the people of Aceh will have the most cases of Covid-19. However, the facts have proven with God's promise that disease will be kept away for those who prosper the mosque. This is in line with the words of the Prophet Muhammad: "Verily, when Allah sends a disease down from heaven to the inhabitants of the earth, Allah will keep the disease away from those who enliven the mosque." (Narrated by Ibn Asakir and Ibn Adi). Rasulullah Saw also said: "Verily I intend to bring down punishment to the inhabitants of the earth, so when I see people who enliven My houses, who love each other because of me, and people who ask forgiveness at dawn, then I will take away the punishment. of them (HR. Al-Baihaqi). Furthermore, the Prophet also said: "If a disease is sent down from the sky, it will be kept away from those who enliven the mosque." (Narrated by Al-Baihaqi). Some of these histories lead to the conclusion that in a situation of epidemics and viruses that threaten the people of Aceh who are the majority of Muslims, it is recommended to be more diligent in going to the mosque, not leaving the mosque. then not allowed to go to the mosque.

If it is related to what is conveyed in the Al-Qur'an that every chanting of the name Allah (Asma Allah) will have a positive effect on the human body. As in Surah Ar-Ra'd verse 28: "(Namely) those who believe and their hearts will be at peace by remembering Allah. Remember, only by remembering Allah will the heart be at ease. " (Implementation Team of Mushaf Pentashihan Al-Qur'an, 2010: 253). This is a traditional relationship between prayer and dhikr together on one's health, because a calm soul will bring positive thoughts so that one's immunity increases and can ward off / reject viruses around them. In addition, in the tradition of rejecting reinforcements, it is recommended that every village citizen enforce the amar makruf nahi munkar. As we know that if an area is already filled with immorality, Allah's punishment will come, as in the previous stories told in the Qur'an. So the Acehnese people are very obedient to what the ulama say, this is because the people of Aceh are very close with scholars. In addition to making efforts, namely by maintaining health guidelines, the people of Aceh also prioritize praying to Allah, both in the five daily fardhu prayers and outside the fardhu prayers, in order to reject reinforcements. In the face of Covid-19, the Aceh Ulama have encouraged Muslims to read the qunut nazilah in fardhu prayer. Plus prayers, and dhikr after prayer, it is mandatory to hope that the corona virus or Covid-19 outbreak will end soon. This is in accordance with MUI fatwa Number 14 of 2020 "Muslims to get closer to Allah by increasing worship, repentance, istighfar, dhikr, reading Qunut Nazilah in every fardhu prayer, increasing prayers, increasing alms, and always praying to Allah SWT so that given protection and safety from calamity and distress (prayer daf'u al-bala '), especially from the Covid-19 outbreak. " As for the recitation of the Qunut Nazilah prayer, it is carried out at every fardhu prayer in the last rak'ah after bowing with a prayer reading, which means: "O Allah, give me directions like the people whom You have instructed. Give me health like the person you have given me. health. Lead me together with those whom You have led. Give blessings on all that You have led. Give blessings to everything that You have given me. And protect me from the evil that You are sure. For in fact You are the one who determines and no one punishes (determines) You. Surely it will not despise those whom You have given power. . And it will not be glorious to those whom You are against. Blessed are You and Glorious are You. Praise be to You for what You have confirmed. I beg your forgiveness and repentance to You. May Allah give mercy and greetings to our lord Prophet Muhammad SAW and all his family and friends. "Meanwhile, outside the fardhu prayer, there is local wisdom that goes on in the life of the Acehnese people, namely reading the Al-Israa 'verse 81, which means:" And Say : The truth has come and the vanity will perish. Indeed, the false will certainly disappear. " (Implementation Team for the Pentashihan Mushaf Al-Qur'an, 2010: 291) In addition, reading (prayer) Yes latif ..., and various other reading models related to rejecting this reinforcement. These are the forms that Aceh Muslims take. in getting closer to Allah, as an effort to stay away from reinforcements or non-natural disasters (Covid-19). This prayer is not only intended for the people of Aceh, but also for other communities outside Aceh.

Humans always passed down a culture from generation to the next generation. Culture and community behavior are formed because they influence each other in life. Likewise with the culture in Acehnese society is as the culture of refusing reinforcements or overcoming some problems, such as contracting diseases in everyday life. The Acehnese nation is famous for its strong religious and cultural identity. Culture as a symbolic system certainly has meaning in every ritual (activity) of that culture. Also, the culture of the Acehnese people to overcome the Covid-19 problem leads to the theory of symbolic interaction. According to Jarome Manis and Bernard Meltzer in Littlejohn, there are seven basic propositions of symbolic interaction, which in essence are that: Humans understand something, through meaning obtained from 
experience. Human perceptions always appear using symbols; The meaning is learned through interactions between people, and meaning emerges from the exchange of symbols in social groups; All social structures and institutions are based on interactions between people; Human behavior is not only influenced by events, but by his own will; The human mind contains internal conversations, which reflect that it has interacted with other people; Behavior created in interactions with social groups; A person cannot be understood only from open behavior but must be as a whole (Deddy Mulyana, 2001: 3). (Deddy Mulyana, 2001: 3). A human being can translate the symbols that have been agreed upon together. Cultural and religious factors have a relationship with medicine, on the one hand, these two factors are relevant in medicine because they influence beliefs about the nature of the disease and their ability to cope with the disease or adhere to recommended treatments (Schiavo, 2007: 76). Traditions, customs, ethnicity, culture, religion, and beliefs also influence ideas of health and disease between various groups. In health communication, these values and beliefs are very important in designing and implementing programs that can reach across cultural boundaries and produce behaviors and societies (Schiavo, 2007: 71).

\section{Conclusion}

The Covid-19 case in Aceh first appeared on March 23, 2020. All positive cases of corona in Aceh did not come from local transmission but were transmitted by residents who visited the red zone and were confirmed positive upon arrival. The Covid-19 disaster requires togetherness and solidarity from all parties to overcome it. The role of the government as a policymaker, the people obeying and implementing it well is a role that is needed by citizens. The formation of the Covid-19 Handling Group to the village level is a form of community togetherness, can also be realized by helping those who are affected. According to reports from the Aceh Covid Group and the Indonesian Covid Task Force, June 2, 2020, 14 districts/cities in Aceh are in the green zone, and only a small portion is in the red zone with a small number of PDP, namely 20 PDP people, 17 recovered, 2 under treatment and one person died, so Aceh must become a pilot area for handling Covid-19. Aceh is considered successful in suppressing the spread of the Coronavirus because of the community's obedience to their leadership in various ways. One of them is the appeal conveyed by the scholars to obey in terms of maintaining religious obligations. One of the traditions of the Acehnese people that has been carried out from generation to generation in order to reject the corona outbreak is to pray and recite together. This tradition is carried out by walking around the city or village while carrying a torch and reading prayers and remembrances.

\section{References}

Abubakar, Marzuki. (2017). Syari'at Islam di Aceh: Sebuah Model Kerukunan dan Kebebasan Beragama. Banda Aceh: UIN Ar-Raniry, https://jurnal.ar-raniry.ac.id.

Ardianto, Elvinaro, dan Q-Anees, Bambang. (2007). Filsafat Ilmu Komunikasi. Bandung: Simbiosa Rekatama Media.

Aw, Suranto. (2015).Implementasi Teori Komunikasi Sosial Budaya Dalam Pembangunan Integrasi Bangsa. Jurnal Informasi: Kajian Ilmu Komunikasi. 45(1). 65-72, do-10.21831/informasi.v45i1.77712015.06.01

D. Ruben, Brent, \&P. Stewart, Lea.(2014). Komunikasi dan Perilaku Manusia. Edisi Kelima. Jakarta: PT Raja Grafindo Persada.

F. Saenong, Faried, dkk.(2020). Fikih Pandemi: Beribadah di tengah wabah. Cet. 1. Jakarta Selatan: Nuo Publishing.

H. Muhibuddin Waly al-Khalidy, Abuya, dkk.(2008). Penegakan Syariat Islam Dalam Perspektif Ulama Aceh, dalam buku Kajian Tinggi Keislaman: Apresiasi Pemikiran Ulama Aceh. Banda Aceh: Percetakan Magenta.

Hefni, Harjani. (2015). Komunikasi Islam. Jakarta: Prenadamedia Group.

J. Moleong, Lexy. (2005). Metodologi Penelitian Kualitatif. Bandung: Remaja Rosdakarya.

Kholil, Syukur.(2006). Metodologi Penelitian Komunikasi, Bandung: Citapustaka.

Mulyana, Deddy. (2001). Perkembangan Teori Komunikasi, Bahan Ajar.

Schiavo, Renata. (2007). Health Communication: From Theory to Practice. San Fransisco: Jossey- Bass.

Sugiyono. (2017). Metode Penelitian Kuantitatif, Kualitatif. Dan R \& D. Bandung: CV. Alfabeta. 
Tim Pelaksana Pentashihan Mushaf Al-Qur'an. (2010).Alhidayah: Al-Qur'an Tafsir Perkata Tajwid Kode Angka.Jakarta: CV. Kalim.

Tubbs, Stewart L., \& Moss, Sylvia. (2005). Human Communication. Buku Pertama \& Kedua. Bandung: PT Remaja Rosdakarya.

W. Creswell, John. (2009). Research Design: Qualitative, Quantitative and Mixed Methods Approaches3rded.California: SAGE Publications Inc.

W. Littlejohn, Stephen, \& A. Foss, Karen. (2016). Encyclopedia of Communication Theory, Terjemahan Tri Wibowo BS. Jilid 2. Jakarta: Kencana.

ZA, Safrizal, dkk. (2020). Pedoman Umum Menghadapi Pandemi Covid-19 Bagi Pemerintah Daerah: Pencegahan, Pengendalian, Diagnosis dan Manajemen. Jakarta: Tim Kerja Kementerian Dalam Negeri Untuk Dukungan Gugus Tugas Covid-19. 